The force of events: the 'Brexit interval' and popular aspirations for Gibraltarian diplomacy

The force of events: the 'Brexit interval' and popular aspirations for Gibraltarian diplomacy

Authors: Jason Dittmer*, Sarah Kunz, Anna Cutmore, Lauren Brigati, Georgia Buckley, George Budd, Isobel Duxfield, Lena Fricker, Matilda Harris, Nicole Holt, Nicolas Koedjikov, Xiaolin Li, Edward Martin, Sarah O’Sullivan, Samuel Parr, Elizabeth Read, Joelle RobinsonRawdah, Filip Veintimilla Ivanov, Cosima Weiss, and Fanqi Zhou

UCL Geography

Pearson Building

Gower Street

London WC1E 6BT

*Corresponding author: j.dittmer@ucl.ac.uk

Abstract: This article highlights both over-reliance on legal perspectives in the study of paradiplomacy at the expense of more dynamic understandings of agency, and also the affective force of waiting and other temporal states on political subject formation.

Empirically, we report the results of a longitudinal study on Gibraltarians' concerns over the Gibraltar-Spain frontier. By comparing data from two identical surveys conducted a year apart during the period between the Brexit referendum and the (as yet incomplete) legal withdrawal, we trace the force of the incomplete event on political subjectivities. Conceptualising our findings through assemblage theory and paradiplomacy, we highlight that the intensity of the event has heightened Gibraltarians' dissatisfaction with their constitutional reliance on the UK to resolve Brexit in a way advantageous for Gibraltar. A minor shift occurred in the year studied towards more agentic proscriptions of what the Government of Gibraltar ought to do to resolve Brexit. Quantitative analysis reveals that younger respondents tend to emphasise this more agentic view, while older respondents 
The force of events: the 'Brexit interval' and popular aspirations for Gibraltarian diplomacy tend to advocate further lobbying of the UK or feel Gibraltar has a complete lack of agency. Qualitative analysis of the respondents' policy proscriptions reveals a complex set of views within each perspective on agency.

Key words: Paradiplomacy, affect, assemblage, surveys, somatic markers, temporality 
The force of events: the 'Brexit interval' and popular aspirations for Gibraltarian diplomacy

\section{Gibraltar and Brexit}

Situated astride the western entrance to the Mediterranean Sea, the British Overseas Territory of Gibraltar has been for centuries near the centre of geopolitics. First it was the 'key to Spain' through which Islamic armies poured in the middle ages, and through which they retreated during the Reconquista. Later it was seized by England and took the form of the 'key to the Mediterranean': a mountainous fortress that offered the possibility to the Royal Navy of controlling the chokepoint and thereby dividing the Atlantic and Mediterranean fleets of both Spain and France (Hughes 1981). The British decision to save Gibraltar at all costs contributed to the loss of the North American colonies; in World War 2 Gibraltar served as the key pivot point for the Allied invasion of North Africa (Bradford 1971). In short, this tiny territory of $6.7 \mathrm{~km}^{2}$ has loomed larger than its size warrants.

Despite this geopolitical significance, the citizens of Gibraltar have not always been prioritised. Derided by the British military for centuries as 'Rock lizards' and denied civil rights on account of the military function of the fortress, those who lived in Gibraltar suffered the trials and tribulations of war but were not recognised as a people in their own right. In World War 2 the women, children, and aged of Gibraltar were forcibly evacuated to London, Northern Ireland, and Jamaica to make the base battle-ready. It was this experience - and the long effort required to shame the British into returning everyone after the war that ultimately galvanised the claim to nationhood that underpinned the formation of ministerial government in the latter half of the $20^{\text {th }}$ century (Azopardi 2009).

Nevertheless, Gibraltar was never likely to de-colonise with the rest of the empire; British military spending underpinned the economy until the 1980s, and beyond that its legal status was particularly fraught. Article $X$ of the 1713 Treaty of Utrecht stipulates that if ever the UK gave up its claim to sovereignty over Gibraltar, it would revert to Spain, which 
The force of events: the 'Brexit interval' and popular aspirations for Gibraltarian diplomacy has maintained a claim on Gibraltar since it was lost in the War of the Spanish Succession. Therefore, it is argued that an independent Gibraltar is not possible (c.f. Lincoln 1994). This has left Gibraltar as one of the 14 Overseas Territories of the UK. These territories have had as much self-governance pushed to them as possible, with the UK remaining in charge of both foreign affairs and defense. The liminality of Gibraltar's position - geopolitically significant but lacking in full autonomy - became readily apparent in the $2016 \mathrm{EU}$ Referendum, when Gibraltar (the only British Overseas Territory in the EU) campaigned to remain in the EU, to no avail.

The Yellowhammer document, demanded by the UK Parliament during a peak in the manoeuvring over Brexit in September 2019, was a statement of the Government's assumptions regarding the worst-case (i.e., 'no deal') Brexit scenario looked like. Section 12 of the document documented the assumed impacts on Gibraltar:

Gibraltar, due to the imposition of border checks at its border with Spain (and the knock-on effect of delays from the UK to EU), will see disruption to supply of goods (including food), medicines, trans-frontier shipment of waste and delays of $4+$ hours for at least a few months in the movement of frontier workers, residents and tourists across the border. Prolonged border delays over the longer term are likely to adversely impact Gibraltar's economy. Like the UK mainland, cross-border services and data flow will also be disrupted. (UK Government 2019, 4)

The threat of Brexit to Gibraltarians' everyday life looms large in Gibraltar. This article considers the affective impact of Brexit, with a particular focus on the way it changed Gibraltarians' expectations of their ability to influence international events.

We argue that the current situation offers the opportunity to not only study the (para)diplomatic agency of non-state polities, but also the way that agency is socially 
The force of events: the 'Brexit interval' and popular aspirations for Gibraltarian diplomacy experienced and understood. Recent work has highlighted the agency of non-state diplomatic actors, valorising this pluralisation of the international system (Beier 2009; McConnell 2016a; Visoka 2019; Rezvani 2016; see also Riegl, Doboš, and Bečka (2019) and Rezvani 2019). We argue, however, that the comparative legalistic approach to paradiplomacy (e.g., examination of constitutional arrangements, competencies, etc.) that dominates scholarship on the topic misses out on the dynamism of public expectations for diplomatic agency, which can vary. Our research indicates that the impact of the Brexit event (or events) on Gibraltarians' understandings of their diplomatic agency was to both elevate their expectations and to lower them.

In contrast to the legalism of much paradiplomacy literature, a recent focus on Deleuzean thought in international relations and political geography has drawn attention to the dynamic world of force relations, and the various temporalities at which they unfold (Lundborg 2012; Dittmer 2017; Ingram 2019). Brexit has been approached from this perspective (Ingram 2017; Anderson and Wilson 2018), providing perhaps a paradigmatic example of a Deleuzean 'event' - notable not only for the struggles over whether it will happen, but also over when it will happen (Widder 2008; Brassett and Clarke 2012). More accurately, we might think of Brexit as occurring multiply, with various affects unfolding in space and time from 2016 (or before) to the present. In this article we will focus on the affective power of the 'Brexit interval', which is the period of existential uncertainty that spooled out endlessly after the 2016 EU referendum. These affective forces ripple not only through the state system, but through the individual bodies of Gibraltarians, producing changes in collective and individual subjectivities.

After reviewing these debates, we detail the results of a longitudinal survey of Gibraltarian residents' views on the border and Brexit. This survey was conducted once from 
The force of events: the 'Brexit interval' and popular aspirations for Gibraltarian diplomacy

31 March-1 April 2018 and again 11-12 April 2019, with the latter survey occurring in the shadow of a potential no-deal Brexit crisis. This allows for an understanding of the Brexit event's unfolding through time and space, and for an empirical grasp of its affective power over Gibraltar residents' political subjectivities. Their expectations of the Government can be seen to be a mix of flux and stability. We conclude by noting that people's expectations of their polity's diplomatic capabilities are emergent from a range of intersecting force fields, mediated by their own embodied experiences, and that the impact of an event can be felt even when the parameters of the event are still being negotiated, as was the case for Brexit at the time of this study.

\section{Literature review}

The Gibraltar context

In 1936 the British forces in Gibraltar watched as Francisco Franco and his allies invaded the Spanish Republic (he had been based in Spanish Morocco), his ships ferrying troops across the Strait (Rankin 2017). Thirty years of fascist rule later, in opposition to a 1967 constitutional arrangement between Gibraltar and the United Kingdom (which shifted the territory's emphasis from being a military fortress to a civilian-based polity), Franco sealed the frontier between Gibraltar and Spain at the northern edge of the isthmus. Then, as now, that frontier consists of a single checkpoint, on the only road from Gibraltar to Spain. This effectively turned Gibraltar into an island, with labour and trade flows from Morocco and beyond sustaining the economy.

This experience - which looms large in narratives of Gibraltarian identity (see Canessa 2018) - only came to an end in 1985, after Franco himself had died and a newlydemocratic Spain was set to join the European Union. Gibraltar, under the aegis of the 
The force of events: the 'Brexit interval' and popular aspirations for Gibraltarian diplomacy

United Kingdom, was already part of the European Union (although not part of the Customs Union or, like the UK, the Schengen zone of ID-less travel) and so the principle of the free movement of people was about to force open the frontier anyway (Spain joined the EU on 1 January 1986). Over the next thirty years, the UK government occasionally turned to the EU Commission in order to rebuke Spain for its perceived over-vigorous policing of the frontier (Garcia 2016; Mut Bosque 2017), which can cause logistical nightmares for Gibraltar (more than 10,000 workers commute across the border every day, and Gibraltar receives more than 12 million tourists a year, many day-trippers from Andalucia).

Fast forward to 2020. The withdrawal of the UK (with Gibraltar) from the European Union has reawakened the ghosts of Franco's frontier closure. Now that the frontier is an external border of the EU, the Gibraltarian economy is vulnerable to disruption by the government in Madrid, and a UK desperate to achieve market access will not be in a strong position to protect it. The Spanish see a scenario in which they might win co-sovereignty or even re-gain the Rock for themselves. This is evident in recent controversies over the EU designating Gibraltar a 'crown colony' of the UK despite British and Gibraltarian objections (Reuters 2019). Brexit, ostensibly not about ancient geopolitical feuds among erstwhile allies, but about trading blocs, supranational regulation, and customs arrangements, is nevertheless haunted by these events from the recent and not-so-recent past. To understand how the Brexit event - as viewed from Gibraltar - is comprehensible through this multiplicity of pasts in the present, we must consider the relational, materialist ontology of assemblage.

Assemblage, temporality, and the event

This project is grounded in an understanding of politics rooted in the interaction of various assemblages. Assemblages are 'wholes characterised by relations of exteriority' (DeLanda 
The force of events: the 'Brexit interval' and popular aspirations for Gibraltarian diplomacy 2006,10 - emphasis in original). That is, assemblages are composed of various elements (bodies, objects, texts) that are not limited to their function in the assemblage but can instead be part of multiple assemblages (Anderson and McFarlane 2011). For instance, to choose a Brexit/Gibraltar-related case, when Royal Marines boarded the Iranian oil tanker Grace 1 in Gibraltarian waters in July 2019, they did so as forces of the UK state, but at the invitation of the Gibraltarian government and also as a performance of the EU's sanctions on Syria (where the tanker was putatively headed - see Daragahi 2019). The Royal Marines were multiply enmeshed in three polities' foreign policy apparatuses (Dittmer forthcoming).

These relations of exteriority mean that assemblage theory hypothesises a flat ontology in which (for instance) individual bodies can be understood as assemblages, enmeshed in larger state assemblages through their performances of state-ness (Painter 2006; Legg 2009). We can then see the idea of the state as a structure, scale, or agency 'above' the individual as itself an emergent effect of the state assemblage. Another consequence of this definition of assemblages via relations of exteriority is that assemblages can affect one another if they are conjoined by a common element (or chain of elements), with intensities rippling through (and re-ordering) space. Assemblage theory can therefore be described as a theory of becoming, with a constant flux of affect coursing through the sinuous relations that compose the whole (Connolly 2011; Dittmer 2014). Most of the time these intensities will only have superficial effects, and the assemblage will appear to be stable (even as it constantly changes - see Shaw 2012). However, occasionally an intensity powerful enough, or the resonance of several smaller affects, can cause an assemblage to tip into a new constellation of relations. This is an event.

Events are usually imagined as spectacular things, known by their obviousness and visibility. For instance, Ingram $(2019,17)$ describes a geopolitical event as 'a disruptive 
The force of events: the 'Brexit interval' and popular aspirations for Gibraltarian diplomacy transformation of the world and of ways of sensing and making sense of it'. We agree that there is an ontological and epistemological dimension to events. 'Highlighting sensation, sense-making and the relations between them allows us to understand geopolitical events as being aesthetic as well as political.' We would emphasise that, given the flat ontology of assemblage and their relations of exteriority, an event can start quite small and eventually ripple through the baroque relations that compose assemblages to emerge as 'large' or evental only in retrospect. Ingram (2017) similarly argues that events occur both 'above' and 'below' the spatial and temporal horizons of human perception all the time, because the human body has evolved to have certain perceptual capacities which can be enhanced through technology but which ultimately embed an anthropocentrism in our political perceptions that is difficult to overturn. To be described as an event, things must necessarily enter into the human sensorium (technologically-aided or otherwise).

Brexit is easily understood as an event, but after that initial naming the road becomes more challenging. If Brexit is/was an event, when is/was it? Was it the 23 June 2016 referendum which produced the mandate for change? Was it the 31 January 2020 departure of the UK (and Gibraltar) from the European Union? Was it the process of departure itself, stretching out before and after any legal departure date? Perhaps, indeed, Brexit stretches before the referendum itself, dating back to other events that set the stage for the populist uprising seen in the referendum results (such as the Eurozone crisis and the Mediterranean migrant crisis - see also Bachmann and Sidaway 2016). As Ingram $(2019,17)$ argues,

From a genealogical perspective, it is not possible to specify with precision or finality what any particular event [...] is, partly because such designations are understood as 
The force of events: the 'Brexit interval' and popular aspirations for Gibraltarian diplomacy

being (in however small a way) part of the event itself and as thereby contributing to its ongoing actualisation.

In this article we adopt this more process-oriented concept of the event, seeing it as congruent with the complex causation of the assemblages unfolding here. Connolly (2017) argues that the affective force of processes unfolding at various temporalities can be understood as 'force fields', which each bear with them an affective force. For instance, we can see climate change as a complex process that - because of the various interactions between the climate system and the geopolitical world - is affecting various elements of the state system (and of course beyond) in ways that are difficult to predict. The difficulty of prediction comes from the way different force fields - of greater or lesser duration intersect with one another to create events.

Further, we rely on the flat ontology of assemblage theory to indicate the transscalar interconnection between Brexit as a state/diplomatic event and Brexit as an event in the everyday lives of people; each is caught up in the other. Anderson and Wilson (2018, 291) argue that

What very quickly became named and known as 'Brexit' saturated everyday life in multiple, disjunctive ways; becoming as the exhilaration and joy of the return of something lost and the possibility of unspecified, better futures to come ("sovereignty", "control", "Britishness"), and the despair and worry of an unsettled present foreshadowed by future losses...

Therefore, it seems clear that Brexit must be understood both as punctuating moments (the vote, the actual rupture) and as a set of affects (hope, uncertainty, fear) that are generated by the untangling (or dis-assembling) of long-standing institutional and everyday 
The force of events: the 'Brexit interval' and popular aspirations for Gibraltarian diplomacy arrangements (such as the Gibraltar-Spain frontier regime). Anderson and Wilson (2018, 293) suggest that scholars

might begin with asking how people, groups, and organisations relate to Brexit through the making present of diverse futures in the interval between the decision to leave, the start of the formal process of exiting, and the final date of exit.

While Anderson and Wilson seem to be talking primarily about the United Kingdom proper, our concern is primarily with the people of Gibraltar. Nevertheless, our project is precisely about this temporality of the Brexit interval - the time between, and the way that this temporality has an agency of its own. In the next section, we review the literature on diplomatic agency and (para)diplomacy, critiquing this literature for being inattentive to the dynamic expectations of the populations that paradiplomacy is meant to represent to the state system.

\section{Paradiplomacy and the British Overseas Territories}

The commonly held definition of diplomacy as the practice of international relations, with its state-centric assumptions of the international system, remains the most colloquial use of the term (Berridge 2015). This is despite the expansion of the term in many corners of political geography, IR, and political sociology to refer to the activities of a range of nonstate (or perhaps state-ish) actors. Diplomacy remains one of the key venues through which actors perform state-ness (Painter 2006), with one of diplomacy's key effects literally being the mutual recognition of statehood. In general, this view of diplomacy as a practice and a performance that is itself worthy of analysis is congruent with the practice turn in IR (Pouliot 2010; Adler and Pouliot 2011; Adler-Nissen 2012). This analytical approach to diplomacy is articulated by Sending, Pouliot, and Neumann (2015) as being performative of both the polity being represented and the authority of the diplomat doing the representing. 
The force of events: the 'Brexit interval' and popular aspirations for Gibraltarian diplomacy

Such an approach opens the door to paradiplomacy, or the 'international activities and foreign policy capacities of substate political units (Woolf 2007), sometimes including cities but, more commonly, referring to regional governments' (Jackson 2018, 3). Cornago (2010) argues persuasively that paradiplomacy is effectively caught in a box - states encourage such efforts where it will maximize outcomes (i.e., good governance, state power, or some other formulation) but discourages it when and where it may interfere with the exclusivity of more traditional diplomacy within the club of states. This tension is neatly summarised by Jackson $(2018,3)$, who argues that 'acceptance of some forms of paradiplomacy by states is a mechanism through which they limit its overall scope.' This sense of paradiplomacy's liminality - as well as the liminality of those who practice it pervades the literature (McConnell, Moreau, and Dittmer 2012; McConnell 2016b).

Certainly the paradiplomacy of Gibraltar and the other British Overseas Territories fits into the box of liminality described by Cornago and Jackson. The ad hoc constitutional arrangements that the UK had allowed to proliferate among its far-flung colonies in the late $20^{\text {th }}$ century were consolidated via two White Papers with highly alliterative titles: Partnerships for Progress and Prosperity (1999) and Security, Success and Sustainability (2012). The 1999 White Paper encouraged a new set of constitutions to be produced throughout the Overseas Territories (Clegg 2013; Clegg and Gold 2011), including in Gibraltar (2006), with the intent of minimizing criticism from the Decolonisation Committee of the United Nations. These constitutions were an advance in terms of self-government, but the 2012 White Paper goes further by explicitly stating that 'The UK Government is responsible for the external relations of the Territories but we encourage Territory Governments to play an active role in building productive links with the wider world' (FCO 2012 , 79). This is a classically liminal statement of the Overseas Territories' agency, 
The force of events: the 'Brexit interval' and popular aspirations for Gibraltarian diplomacy reserving the agency to the UK but authorising 'productive links' to be forged by the Territories' governments (see also Rezvani 2015). Legally, this tension is handled by the British Foreign and Commonwealth Office's deployment of 'letters of entrustment' that authorise government officials from the Overseas Territories to represent themselves in narrowly defined forums. In practice, however, the Overseas Territories represent themselves all the time, not least to the UK itself (McConnell and Dittmer 2018). For Gibraltar, as the only British Overseas Territory that was in the EU, this also entailed a permanent representation in Brussels (recently expanded in 2014), and also practical engagement with local authorities in La Linea (the town on the other side of the frontier).

This multi-scalar form of governance was referred to by Gad and Adler-Nissen (2013, 1) as postcolonial sovereignty games, with sovereignty "not a "thing" that is either present or absent. On the contrary, sovereignty unfolds in the legal and political games [between the Overseas Territory, the state, and the supranational EU] that must be studied as both discourses and practices.' Rather than seeing this via a hierarchical imagination with Gibraltar at the bottom, the UK in the meso-scale, and the EU above them both, Gad and Adler-Nissen are hinting at a much more complicated scenario, in which space and authority are folded over on themselves, in a topological form. Such an imagination calls on us to think not through Bourdieu and the practice turn; rather the spaces of folds and topology belong to the aforementioned Deleuzean philosophy (Buchanan and Lambert 2005). The paradiplomatic practices of Gibraltar and the other Overseas Territories are not just legal/illegal practices (as the letter of entrustment would indicate) but rather are productive relations generative of political affects (Protevi 2009). These affects shape the processes that lead to political cognition, both in political elites individually and in broader collective subjects, like Gibraltar (Dittmer 2017). We argue, therefore, that paradiplomacy research 
The force of events: the 'Brexit interval' and popular aspirations for Gibraltarian diplomacy

has largely focused on governments rather than everyday lives, where affects circulate that shape people's expectations of governmental agency. Here, we argue that the Brexit interval - with its peaks and troughs of activity and crisis - has worked to re-shape Gibraltarians' expectations of their government and its (para)diplomatic agency.

In the next section we turn to our methodology, which utilised survey methods to assess changes to political subjectivity in response to the affective power of the Brexit interval. If this seems an abrupt transition - assemblage theory and surveys are rarely linked - we see it as a way of understanding how individual bodies are being differentially impacted by the affective politics of Brexit and the Gibraltar-Spain frontier (Baker and McGuirk 2017; Colls 2012).

\section{Methodology}

This research is based on two surveys carried out in Gibraltar with approximately one year separating them. The first was conducted between 31 March - 1 April 2018, while the second was conducted 11-12 April 2019. The first survey occurred almost two years after the Brexit referendum, but several months before the EU Withdrawal Agreement was concluded. The second survey occurred in the immediate shadow of a no-deal Brexit (first pushed back from 29 March 2019 to 12 April 2019, and then just as the survey was to start it was pushed back to 31 October 2019). Therefore, the two surveys occurred at two different phases of the Brexit 'event', with vastly different affective valences. The surveys were in all other ways identical, and so they allow for comparison of Brexit affects on Gibraltarian political subjectivity.

Respondents had to be 18 years of age or older and 'usually resident' in Gibraltar; this was interpreted as living in Gibraltar over the previous 12 months or intending to live in 
The force of events: the 'Brexit interval' and popular aspirations for Gibraltarian diplomacy

Gibraltar for more than 12 months overall. Respondents could be of any citizenship, but UK military personnel and their families were excluded. Initial data collection for the 2018 survey was conducted in pairs, focusing on the major leisure areas of Casemates Square/Main Street and Ocean Village/Waterport. However, this approach found many tourists and not many residents, and so data collection shifted outside the fortress to residential areas on reclaimed land in Northwest Gibraltar. This area led to improved completion rates and served as the basis for the 2019 survey. A quota sample organized around gender parity and age distribution served as the demographic basis of the survey, using the 2012 Census of Gibraltar as a baseline. The profile of survey respondents matched the census with regard to age distribution. In the end, the 2018 survey undercounted women (45\% of 292 respondents) while the 2019 survey overcounted them by a similar amount ( $55 \%$ of 286 respondents). The survey was done in English, the official language of Gibraltar. Gibraltarians are generally bilingual (or trilingual, if you include Llanito, the local dialect) with Spanish more popular among older residents and English more popular among the young. The quota sampling ought to account for this bias, although English tends to have higher class connotations and so there may be a bias towards the middle and upper classes, especially in the older stratum of the sample. It may also exclude Spanish citizens living in Gibraltar (although most of the Spanish workforce lives across the frontier). All 578 respondents were provided an information sheet about the survey and gave their informed consent.

The survey questionnaire had four sections, beginning with closed-ended questions and concluding with open-ended questions; this allowed respondents to get comfortable with the survey before being asked about political issues (McLafferty 2016). The first section asked a series of demographic questions, while the second section focused on the 
The force of events: the 'Brexit interval' and popular aspirations for Gibraltarian diplomacy respondents' current relationship to the frontier. How often did they encounter it? Do they have family, friends, or property on the other side of the frontier? The final question in this section asked respondents how they felt about the frontier, in an effort to understand their affective relationship to it (this is the subject of another article - Dittmer et al. 2019).

The third section of the survey specifically raised Brexit, asking respondents to predict its impact on the frontier, and on their everyday lives. How would their lives change, and what actions would they individually take to adapt to a changed frontier? The final section of the survey asked respondents to think not of their own everyday lives after Brexit, but of Gibraltar after Brexit. What would the effects of a tighter border regime be on Gibraltar, and how should the Government of Gibraltar respond to this challenge? Finally, respondents were offered the chance to add their own comments at the end of the survey.

These final three questions ('effects of Brexit', 'Government of Gibraltar action', and 'any other comments') are at the crux of our analysis in this paper. A qualitative (noncomputerised) sentiment analysis was conducted in which each respondent was coded according to their responses to these three questions, although the 'Government of Gibraltar action' question was the first port of call, with the others figuring contextually when necessary. Each respondent was coded with regard to the agency with which she or he narrated the Government of Gibraltar during Brexit. Thus, some respondents argued that the Government of Gibraltar had great diplomatic or other agency (Gibraltar agency), while others argued that it had no diplomatic or other agency at all (Gibraltar no agency). As coding progressed, it became apparent that other codes were necessary. One code was developed for respondents who argued for the Status quo at any cost (such as 'Revoke Article 50', something manifestly not in Gibraltar's remit) while another code was developed for those who thought nothing at all need be done (Embrace Brexit). Another 
The force of events: the 'Brexit interval' and popular aspirations for Gibraltarian diplomacy code (Indeterminate agency) was developed for those who articulated an ambiguous sense of Gibraltarian agency, such as lobbying the UK government (this, arguably, reflects the legal stance of the 2006 Gibraltar constitution, in which the UK is in charge of foreign affairs). A final code was developed for 'other responses', which were frequently non sequitur or otherwise unclassifiable responses. While 'other' and non-responses were included in statistical tests, they are excluded from our discussion of descriptive statistics and qualitative analysis.

Given the nominal nature of most of this data, the survey results for both years were compared using a Chi-squared test, which tests for an association (or difference) between two categorical variables, in this case the Brexit coding and the year of the survey. The null hypothesis for such a test would be that there is no relationship between the two years; it should not be surprising that the alternative hypothesis - that there are indeed similar profiles for each year - largely holds. However, there are key points of variation which we explore below. A second set of Chi-squared tests compared the Brexit codes with key demographic categories, while an independent samples Kruskal-Wallace test did so with regard to age. The statistical variation is of course only part of the picture, and so we use the actual open-ended answers of respondents to flesh out how Gibraltar residents think about Brexit and their Government's agency therein.

\section{Findings and analysis}

\section{Quantitative analysis}

A Chi-squared test compared the 2018 and 2019 surveys with regard to the Brexit codes produced through qualitative sentiment analysis. With a $p$ value of 0.002 it is clear that the surveys fundamentally resemble one another, however there is one clear difference: the 
The force of events: the 'Brexit interval' and popular aspirations for Gibraltarian diplomacy decline in people arguing for Indeterminate agency, which is the code that most clearly maps on to the legal understanding of Gibraltar's diplomatic agency (that is, the ability to lobby Parliament and work with the Foreign and Commonwealth Office) collapsed between 2018 and 2019. We interpret this as a rejection of the status quo with the legal limitations of paradiplomacy, but in favour of what?

Figure 1 more clearly visualises the distribution of codes between the two surveys. It is worth remembering that the 2019 survey is slightly smaller in size than the 2018 survey, and so the expected number of respondents falling into each category ought to be slightly smaller. [INSERT FIGURE 1 HERE] Figure 1 makes it clear that the collapse of Indeterminate agency is in contradistinction to marked rises in Gibraltar has agency and Status quo at all costs. If Status quo at all costs is interpreted as a sort of super-agency, the ability to wish away Brexit, then it is clear that a large proportion of the respondents fleeing Indeterminate agency are seeking greater diplomatic agency by the Government of Gibraltar.

There is also a modest rise in the number of people coded Gibraltar no agency and a decline in the number suggesting that Gibraltar should Embrace Brexit (it should be noted that the $n$ for Embrace Brexit is relatively small, and so small variations seems large). These two categories cannot be aggregated in the same way that Gibraltar has agency and Status quo at all costs can be aggregated, because the former is a statement of agentic capacity while the latter is a normative stance on whether agency ought to be enacted. This perhaps explains the split between the two codes; the affective intensity of the interval led many to seek more diplomatic agency (Gibraltar has agency and Status quo at all costs) while for others the interval led to a sense of futility and doom because of the failure of paradiplomacy to produce a favourable outcome for Gibraltar (Gibraltar no agency). Overall as the potential trauma of Brexit became clearer during the interval, political subjectivities 
The force of events: the 'Brexit interval' and popular aspirations for Gibraltarian diplomacy became reworked such that fewer were complacent about Brexit (decline in Embrace Brexit). However, the survey sample was broadly representative (not statistically representative, it should be added) of the residents of Gibraltar. How did the intensity of the interval affect individuated bodies differently?

A Chi-squared test of the Brexit/agency codes' relation to gender, nationality, religion, and border-crossing behaviour for both years revealed no statistically significant relationships. However, an independent samples Kruskal-Wallace test of age and Brexit/agency coding revealed a statistically significant relationship $(p=0.00)$. This relationship is visualised in Figure 2 , which is a simple boxplot of the variation in age across the Brexit/agency codes. [Figure 2 near here] A simple boxplot visualises numerical data (in this case, age) through its quartiles. That is, the line in the box indicates the median, while the top and bottom of the box indicate the range included within the second and third quartiles. The top of and bottom of each plot indicate the minimum and maximum value for that Brexit/agency code. In short, Figure 2 is an easy way to (imperfectly) examine why the Kruskal-Wallis test revealed a statistically significant relationship between age and Brexit/agency code.

What is apparent from the chart is a substantial age difference between the respondents that endorse agentic (or super-agentic, in the case of Status quo at all costs) notions of Gibraltarian diplomacy and those who adhere to more traditional (or even pessimistic) views on Gibraltarian diplomacy. The median age of respondents for both Gibraltar Agency and Status quo at all costs is under 40, although Status quo skews older in its age distribution within the second and third quartiles. The median age for respondents coded Gibraltar no agency and Indeterminate agency is in the low to mid 50s, with the age distribution appropriately higher; Gibraltar no agency has a relatively high median given its 
The force of events: the 'Brexit interval' and popular aspirations for Gibraltarian diplomacy quartiles, which indicates a clustering of respondents around age 60. Embrace Brexit has a similar median and age distribution to Gibraltar no agency and Indeterminate agency but recall that it both has a small $N$ and is a normative stance on Brexit rather than a particular view on Gibraltarian diplomatic agency. Nevertheless, it may be useful to link these respondents with those who assert that Gibraltar has little to no diplomatic influence, especially when Brexit is pushed to its nihilistic limits (for more on this, see qualitative analysis below).

To summarise our quantitative findings, we would argue that while the profiles of respondents' views on Brexit and Gibraltar's ability to shape events are fundamentally similar from 2018 to 2019, there has been a serious decline in the number of respondents who are coded as Indeterminate agency, and these have been generally replaced by respondents who are coded either Gibraltar agency, Status quo at all costs, and Gibraltar no agency. This is interpreted as the Brexit interval's affective impact on the political subjectivities of Gibraltarians, who are enmeshed in a media/governmental assemblage that enables collective anxieties to become manifest in individual bodies. This has pushed some to advocate for greater Gibraltarian diplomatic agency and has pushed some others to a sense of being out-of-control. These affective forces seem to be refracted through bodies that are shaped differently by time, with the agentic (or super-agentic) view of Gibraltarian diplomacy tending to be held by younger respondents while the less agentic view tending to be held by older respondents. While there are of course young and old in each coding category, it is perhaps indicative that the top of the third quartile for both Gibraltar agency and Status quo at all costs is at or below the median for Gibraltar no agency. This quantitative analysis is - we hope - illuminating. But the Brexit/agency codes are of course an amalgamation of a wide range of views. In what follows we attempt to unpack these 
The force of events: the 'Brexit interval' and popular aspirations for Gibraltarian diplomacy codes, showing the full range of orientations towards diplomatic capability (and Brexit) within.

\section{Qualitative analysis}

The two codes with which the analytical process began - derived from our research interests in paradiplomacy and Brexit - were Gibraltar agency and Gibraltar no agency. As stated earlier, these codes were derived primarily from the 'in your opinion, what should the Government of Gibraltar do?' question, with 'how do you think a tightened border would affect Gibraltarian society?' and 'Any other comments or suggestions' as context to help determine the respondents' view of Gibraltarian agency.

The most obvious way in which Gibraltarian diplomatic agency was articulated was through a call for independence. This was sometimes articulated hesitantly, as in 'Leave the UK and make our own country - but this is not realistic' (respondent 8, 2019 survey, age 29), and sometimes in a more full-throated fashion, as with the claim to an already-existing sovereignty: the Gibraltarian Government 'should fight for their own independence. This is an independent country' (respondent 106, 2018 survey, age 66). In other cases, the question of sovereignty was articulated in a more roundabout fashion. For instance, several respondents to the 2018 survey (before any Withdrawal Agreement was agreed) argued that Gibraltar should 'have our own decision and vote' (respondent 318, age 22) and there should be a 'referendum to see what Gibraltar thinks about the EU and the UK (respondent 262 , age 66). This idea embeds the notion of self-determination at the core of Gibraltarian nationhood, but also ignores the constitutional context in which Gibraltar is embedded. Nevertheless, the latter quote indicates a sense of openness and fluidity to that context, offering tacitly the possibility of other arrangements being possible, including some form of self-governance within the European framework (rather than the British one). The 
The force of events: the 'Brexit interval' and popular aspirations for Gibraltarian diplomacy importance of the EU to Gibraltarian self-governance was highlighted by respondent 221 (2019 survey, age 42), who argued that Gibraltar should gain 'independence from the UK; fight for our right to stay in the EU but do not give sovereignty to Spain.' This points to the role of the EU in 'postcolonial sovereignty games' as highlighted by Gad and Adler-Nissen (2013). Rather, the EU has provided both a legal framework in which Gibraltar was able to speak on its own behalf (that the EU was understood in relation to Gibraltar's domestic affairs, rather than its external affairs, was agreed in the 2006 Constitution of Gibraltar) and also an alternative source of legitimacy beyond the UK.

Beyond calls for independence, referenda, and sovereignty, those coded as Gibraltar agency also called for a range of diplomatic initiatives. These might be categorised in three ways. First, some respondents argued for a deeper diplomatic engagement with Spain, seeing Spain as the key interlocutor. Respondent 108 (2018 survey, age 21) argued for the Government of Gibraltar to 'open talks with Spain to keep things as open as possible,' while respondent 60 (2019 survey, age 40) suggested the Government 'get down from their high throne and realise they need to create a deal with Spain.' Given that Gibraltar has vigorously met with representatives of EU member-states - including Spain - during the Brexit process, this seems to indicate a belief in the capability of Gibraltar to conclude 'a deal' on its own. This may reflect confusion on the part of Gibraltarians on the scope of the deal-making that is authorised by the UK government; while Gibraltar was active in negotiating technical details with Spain around cross-border topics such as taxation, air travel infrastructure, and anti-smuggling measures, it cannot arrive at a 'deal' in the same way that the UK can.

The same belief in Gibraltarian diplomatic agency could manifest in entirely different tone, such as the claim by respondent 138 (2019 survey, age 60) that Gibraltar should 'strengthen ties with places like Morocco and Portugal...links to Commonwealth countries 
The force of events: the 'Brexit interval' and popular aspirations for Gibraltarian diplomacy should be strengthened.' Here reference is made to two other polities in the region of the Straits of Gibraltar, both of which have historically had strong links with Gibraltar (during the frontier closure, Gibraltar imported most of its food and labour from Morocco). Respondent 163 (2019 survey, age 65) and respondent 233 (2019 survey, age 23) also invoked the frontier closure when they called for the Government to 'organise more ferries to Morocco' and to make a 'trade deal with Morocco for food maybe, but under no circumstances relations with Spain.' This instinctive reflex to the diplomatic tactics of the Franco era indicates the triggering of a collective somatic marker (Connolly 2002) in some of the population - some of whom were not even alive at that time - by the affective force of the Brexit interval.

A final version of this call for greater diplomatic engagement threads the needle between these two positions by calling for greater engagement with local Spanish government and with the nations of the United Kingdom. This hews closer to traditional paradiplomacy in that it locates Gibraltar outside of the state system, but recognises it has the ability to engage in relations. For instance, respondent 253 (2018 survey, age 46) argues that 'if Northern Ireland obtains inclusion in the Customs Union and Single Market, the Government should press as hard as we can on that front.' Similarly, respondent 248 (2018 survey, age 62) urges greater 'cooperation with the local region [Andalucía], but not with central government as that is impossible.' Both of these examples indicate the freedom that Gibraltarians perceive within the rhizomatic world of European diplomacy.

The code Gibraltar no agency had fewer permutations, although there was some variation among the respondents. The strongest component of this code was among respondents who explicitly highlighted the hierarchical relationship between Gibraltar and the UK. By way of example, respondent 102 (2018 survey, age 71) argued that 'there isn't 
The force of events: the 'Brexit interval' and popular aspirations for Gibraltarian diplomacy much they can do. Britain is "the master" so they can give us assurance that we will be looked after,' while respondent 251 (2019 survey, age 32) said 'we are a colony; we can't do anything.' This invocation of Gibraltar as a 'colony' is interesting given how averse both the UK and the Government of Gibraltar are to that nomenclature (Reuters 2019). Respondent 328 (2018 survey, age 25) noted the subordination inherent to Gibraltar's position: 'They are doing all they can, putting their faith in the UK government, but there is not much else they can do.' In short, Gibraltar is portrayed as a bit player in the world of states.

A different version of this is not antagonistic to the world of states, but rather is rooted in a sense of congruence between Gibraltar and the UK. In this line of argument, Gibraltar's link to the UK is so strong that their interests converge. For example, respondent 331 (2018 survey, age 56) noted that Gibraltar's government has to 'go with the flow. They can't do much, have to go with the majority.' This description of the situation sublimates the Gibraltarian vote within the larger UK vote to leave the EU, rather than emphasising the strong Remain vote in Gibraltar and their unique interests. A related form of answer emphasised the loyalty of Gibraltar to the UK, which differs from the above in that it does distinguish between the two polities but promotes a voluntary (hierarchical) association between them. 'Impossible for the Gibraltarian Government to change anything. We should stay with the UK through good and bad,' (Respondent 111, 2019 survey, age 52). To summarise, those asserting that Gibraltar had no agency were either arguing for its abject constitutional position in relation to the UK or lamenting Gibraltar's tiny sliver of the overall UK electorate. These stances - which position Gibraltar differently vis-à-vis the UK nevertheless converge in a sense of diplomatic futility.

Nestled uncomfortably between these two codes is Indeterminate agency. This code was not anticipated; rather it was developed during the coding process in response to 
The force of events: the 'Brexit interval' and popular aspirations for Gibraltarian diplomacy survey answers that imagined Gibraltar as having agency, but agency that was nondiplomatic and limited (without being entirely absent). Frequently, this took the form of lobbying the UK government - which flows from the strict reading of the 2006 Constitution and its allocation of Gibraltar's external affairs to the UK. Respondent 47 (2019 survey, age 80) gave a prototypical answer in this vein when she answered that the Gibraltarian Government is 'doing enough by the Chief Minister going to the UK and EU for meetings.' Similarly, respondent 203 (2018 survey, age 51) argued that 'the Government is working hard to get Gibraltar's interests recognised, which is all they can do.' In short, those asserting these views emphasised Gibraltar's ability to exert limited agency through the UK, under certain circumstances.

Other replies included in this code ranged further from Gibraltar's constitutional right to lobby the UK Government to have their interests recognized, and included vague assertions of agency but with limited aims. Respondent 243 (2018 survey, age 49) wanted the Chief Minister to 'try not to let it affect Gibraltarians' (note the emphasis on 'try') while respondent 291 (2018 survey, age 53) urged the Gibraltarian Government to 'remain professional and not retaliate. Think things through without reacting.' Answers such as these impute some ability to shape events without clearly asserting (or denying) diplomatic agency. Recall that it was this category that collapsed between 2018 and 2019, as the Brexit interval re-worked (some) political subjectivities in Gibraltar. We argue that the affective intensities of Brexit made this kind of patient lobbying less palatable to a Gibraltarian population that either wanted a stronger sense of tangible influence over the event's unfolding or that, conversely, gave up on any sense of agency within the event.

The respondents who were coded as Status quo at all costs were imagined above as those advocating a kind of Gibraltarian diplomatic super-agency, in which Brexit could be 
The force of events: the 'Brexit interval' and popular aspirations for Gibraltarian diplomacy unilaterally cancelled or its effects wished away. When considered in its qualitative depth, however, this super-agentic code might also be understood as rooted in an affect of despair emergent from the lack of Gibraltarian agency within the Brexit interval. Perhaps the most plaintive response of this type was respondent 33 (2019 survey, age 35), who simply asked the Government of Gibraltar to 'make sure our lives don't change.' The embodied dimension to this affect was apparent in some comments, such as that of respondent 101 (2019 survey, age 21), who said that 'it's all very unsettling.' Other common responses focused on the border, with Gibraltarian respondents asking for it to remain open, and Spanish or Moroccan residents asking for preferential access to be given to their own nationality. A subset of this code mirrored Remain discourse in the UK, calling for Article 50 to be revoked, or for a new referendum to be held. Some respondents also called into question 'the truth behind how and why people voted in the referendum,' (respondent 116, 2019 survey, age 32).

The final code to be analysed, Embrace Brexit, differs from the above in that it is a response of intentional non-agency towards Brexit. Given only $4 \%$ of the electorate voted for Brexit, we should not be surprised to have encountered so few respondents who could be coded this way. Even with a relatively small $N$, however, several strains of response are possible, especially when the Brexit interval is taken into account. In 2018 , some respondents articulated an isolationist, anti-globalisation view on Brexit; for example, respondent 259 (age 59) arguing that 'so much money is wasted on competing with globalisation; we need to live isolationist.' This same respondent, in answering the question about what the Gibraltar Government should do, replied that he would 'shoot all liberalised elites', mirroring much online discourse around Brexit (Walker et al. 2018). Some drew inspiration from Gibraltar's long history of exploiting loopholes, such as its free port status 
The force of events: the 'Brexit interval' and popular aspirations for Gibraltarian diplomacy (given by Queen Anne), for economic gain (Howes 1946). Shedding EU regulation might give Gibraltar an advantage in, say, the economies revolving around cryptocurrencies.

By 2019, much of the anti-globalisation discourse had dropped out of the Embrace Brexit code. However, what remained was a sharp focus - also discernible in the 2018 surveys - on the possibility of disentangling Gibraltar from economic and social integration with Spain, specifically. For instance, respondent 101 (2018 survey, age 42) saw Brexit as a chance to 'get rid of Spanish workers and people; they work for really low wages, too low for us to compete with'. Respondent 124 (2019 survey, age 44) argued that Brexit 'won't affect us, it will affect La Linea [the neighbouring border town]; we Gibraltarians won't go over and spend money.' This view sees the economic asymmetry between Gibraltar and La Linea as insulating Gibraltar from the shock of severed labour and other markets. Others were less dismissive of the economic shock (temporary food shortages, etc) but thought it would be worth it. Nevertheless, there is a tendency among those coded Embrace Brexit to link EU membership broadly with Spain specifically, as in this quote from respondent 133 (2018 survey, age 59): 'They're backward in Spain. Not forward thinking. [...] The EU is corrupt, and Britain puts in more money than they get back.' Therefore, Brexit can be seen in the particularly Gibraltarian context of several centuries of contestation with Spain.

\section{Conclusions}

In this article, we have articulated the quantitative results of a longitudinal survey of Gibraltarian residents with regard to Brexit and their concerns over their frontier with Spain. This may seem to be an odd way to go about advancing research on paradiplomacy and assemblage theory, but the longitudinal approach allows us to consider the impact of time when linked to the affective forces produced by socio-material processes such as Brexit - on 
The force of events: the 'Brexit interval' and popular aspirations for Gibraltarian diplomacy political subjectivities in everyday life. We would like to briefly summarise our empirical findings before sketching out some conceptual implications.

First, once respondents were coded according to their responses to questions about Brexit and the Gibraltarian Government's agency we found that the affective force of the interval (during which a 'hard Brexit' withdrawal agreement was agreed and in which a 'no deal' Brexit was narrowly avoided) had led to a decrease in the number of respondents who articulated Indeterminate agency, and an increase in the number of respondents who articulated Gibraltar agency, Gibraltar no agency, and Status quo at all costs. A statistically significant distinction can be found in the age of those allocated the more 'agentic' codes in contrast to those allocated the less agentic codes (and also Embrace Brexit), with those advocating more diplomatic agency typically younger than those couching their response in terms of futility or a lack of diplomatic agency.

Second, the qualitative answers on which the Brexit/agency codes are based help to illustrate the range of views encompassed within each. Gibraltar agency had the most diversity, ranging from support for independence, to a range of diplomacies including direct relations with Spain, outreach to non-EU polities for trade purposes, and links to other paradiplomatic entities. Those advocating Gibraltar no agency either saw Gibraltar as subordinate to UK interests, or saw Gibraltar as so completely part of the UK that it had no specific interests. Indeterminate agency advocated for Gibraltarian lobbying within its constitutional relationship to the UK, or for other non-diplomatic forms of Brexit mitigation. Status quo at all costs could be read as either a fantasy of super-agency or a cry of futility, while Embrace Brexit could be read via the broader Leave discourse of the UK or via a Gibraltar-specific conflation of the EU with Spain. 
The force of events: the 'Brexit interval' and popular aspirations for Gibraltarian diplomacy

While it is of course speculation as to what the cause of the age difference is between the different agentic orientations of the respondents, we can posit two key events that preceded Brexit that might account for some of the variation. First, the opening of the Spanish frontier in 1985 (and the Spanish accession to the EU in 1986) physically connected Gibraltarians' everyday lives to a wider Europe. Second, the 2006 constitutional settlement pushed for Gibraltar to do more self-representation in international settings (and authorized Gibraltar to supplement the relationship to the UK with the 'postcolonial sovereignty games' in which Gibraltar represented itself in the EU). Therefore, younger Gibraltarians have only ever known the more confident, agentic Gibraltar. This confidence serves as an affective disposition that enables them to imagine agencies beyond the legal remit of Gibraltar's constitutional settlement, and the crushing of that confidence by the affective force of the Brexit interval might feel disabling. This dichotomous reaction to the force of the interval - inflected by the life experiences of individual Gibraltarians (with 'age' as a proxy for those experiences) - would account for the statistical variation. For older Gibraltarians, a tighter frontier might resonate with their own childhood memories, and thus activate positive affects. More research could shed light on these hypotheses.

Conceptually, we argue that the paradiplomacy literature has largely articulated a legal or theoretical perspective on the diplomacy of non-state polities. What we have tried to do is to push for a more popular understanding of these diplomacies, highlighting how events shape popular expectations for diplomatic agency. This is important, as shifts in such popular expectations can presage calls for statehood (as some respondents in our survey indicated). As McConnell (2017) notes, Estonia and East Timor were paradiplomatic actors before they became diplomatic ones. Assemblage theory allows us to understand the affective forces that enable or disable political elites to assert new diplomatic capabilities. 
The force of events: the 'Brexit interval' and popular aspirations for Gibraltarian diplomacy

With regard to assemblages and events, we have empirically demonstrated the power of affective forces that unfold in the intervals within the event. As Ingram (2019) notes, temporal limits to events are difficult to identify because the determination of those delineations are themselves part of the event. Here we have demonstrated that even without Brexit having 'happened', its affective energies have been re-making Gibraltarian political subjectivities. Thinking through Brexit requires us to link this event to previous events that reside in the somatic markers which form through the intersection of bodies and the various mobilities they enable, such as the frontier closure, its re-opening, and the international self-representation of Gibraltar. All of these shape the collective expectations of the body politic, changing the horizons both of the 'event' and the polity's response to it.

Acknowledgements: The authors would like to thank the students who assisted with the 2018 data collection, without whom this article would not be possible.

\section{Bibliography}

Adler, E. and Pouliot, V. (2011) 'International Practices,' International Theory 3(1): 1-36.

Adler-Nissen, R. (Ed.) (2012) Bourdieu in International Relations: Rethinking key concepts in IR (London: Routledge).

Anderson, B. and McFarlane, C. (2011) 'Assemblage and geography.' Area 43(2): 124-127.

Anderson, B. and Wilson, H. (2018) 'Everyday Brexits,' Area 50(2) 291-295.

Azopardi, K. (2009) Stateless Nation: Gibraltar in the modern legal context (Oxford and Portland: Hart Publishing).

Bachmann, V. and Sidaway, J. (2016) 'Brexit geopolitics,' Geoforum 77: 47-50. 
The force of events: the 'Brexit interval' and popular aspirations for Gibraltarian diplomacy

Baker, T. \& McGuirk, P. (2017) Assemblage thinking as methodology: commitments and practices for critical policy research,' Territory, Politics, Governance 5(4): 425-442.

Beier, J.M. (Ed.) (2009) Indigenous Diplomacies (New York: Palgrave Macmillan).

Berridge, G. (2015) Diplomacy: Theory and practice, $5^{\text {th }}$ edition (New York: Palgrave Macmillan).

Bradford, E. (1971) Gibraltar: The history of a fortress (London: Hart-Davis).

Brassett, J. and Clarke, C. (2012) 'Performing the Sub-Prime Crisis: Trauma and the Financial Event,' International Political Sociology 6(1): 4-20.

Buchanan, I. and Lambert, G. (2005) Deleuze and Space (Toronto and Buffalo: University of Toronto Press).

Canessa, A. (Ed.) (2018) Barrier and Bridge: Spanish and Gibraltarian Perspectives on Their Border (Brighton: Sussex Academic Press).

Clegg, P. (2013) 'The United Kingdom and its Caribbean overseas territories: Present relations and future prospects', Caribbean Journal of International Relations and Diplomacy 1(2): 53-64.

Clegg, P. and Gold, P. (2011) 'The UK overseas territories: A decade of progress and prosperity?' Commonwealth and Comparative Politics 49(1): 115-135.

Colls, R. (2012) 'Feminism, bodily difference and non-representational geographies,' Transactions of the Institute of British Geographers 37(3): 430-445.

Connolly, W. (2002) Neuropolitics: Thinking/Culture/Speed (Minneapolis: University of Minnesota Press).

Connolly, W. (2011) A World of Becoming (Durham: Duke University Press).

Connolly, W. (2017) Facing the Planetary: Entangled humanism and the politics of swarming (Durham: Duke University Press). 
The force of events: the 'Brexit interval' and popular aspirations for Gibraltarian diplomacy

Daragahi, B. (2019) 'Iran nuclear deal at threat over UK seizure of oil tanker in Gibraltar,' The Independent, 9 July. Online at https://www.independent.co.uk/news/world/middleeast/iran-nuclear-deal-oil-tanker-uk-seized-gibraltar-tensions-middle-easta8997316.html (last accessed 17 July 2019).

DeLanda, M. (2006) A New Philosophy of Society: Assemblage Theory and Social Complexity (London: Continuum).

Dittmer, J. (2014) 'Geopolitical assemblages and complexity', Progress in Human Geography 38: $385-401$.

Dittmer, J. (2017) Diplomatic Material: Affect, assemblage, and foreign policy (Durham: Duke University Press).

Dittmer, J. (forthcoming) 'Distributed agency: Foreign policy sans MFA,' Hague Journal of Diplomacy. Open access: https://discovery.ucl.ac.uk/id/eprint/10081456/

Dittmer, J., S. Kunz, J. Bocking, C. Brown, H. Cooney, S. Datta, M. de Soissons, E. Dixon, A. Fraser, J. Keene, U. Marshall, S. Mitchell, C. Porter, B. Roberts, A. Sivakumaran, W. Tan, C. E. Thompson, I. Vernon-Avery \& F. Zamula (2019) 'Gibraltarians' attitudes towards Brexit and the Gibraltar-Spain frontier', Space and Polity 23(3): 283-298.

FCO (2012) The Overseas Territories: Security, Success and Sustainability (London: FCO). Gad, U.P. and Adler-Nissen, R. (2013) 'Postcolonial sovereignty games,' in Adler-Nissen, R. and Gad, U.P. (Eds.) (2013) European Integration and Postcolonial Sovereignty Games: The EU Overseas Countries and Territories (London: Routledge), pp.1-24.

Garcia, J. (2016) 'Brexit: A view from Gibraltar,' The Round Table: The Commonwealth Journal of International Affairs 105(5): 585-586.

Gold, P. (2010) 'Identity formation in Gibraltar: Geopolitical, historical and cultural factors,' Geopolitics 15(2): 367-384. 
The force of events: the 'Brexit interval' and popular aspirations for Gibraltarian diplomacy

Howes, H. (1946) The Story of Gibraltar (London: Philip \& Tacey).

Hughes, Q. (1981) Britain in the Mediterranean \& the Defence of her Naval Stations (Penpaled Books).

Ingram, A. (2017) 'Geopolitical events and fascist machines: Trump, Brexit and the deterritorialisation of the West,' Political Geography 57: 91-93.

Ingram, A. (2019) Geopolitics and the Event: Rethinking Britain's Iraq War Through Art (New York: Wiley)

Jackson, T. (2018) 'Paradiplomacy and political geography: The geopolitics of substate regional diplomacy,' Geography Compass 12(2):

https://onlinelibrary.wiley.com/doi/full/10.1111/gec3.12357

Legg, S. (2009) 'Of scales, networks and assemblages: The League of Nations apparatus and the scalar sovereignty of the Government of India,' Transactions of the Institute of British Geographers 34: 234-253.

Lincoln, S. (1994) 'The Legal Status of Gibraltar: Whose Rock is it anyway?' Fordham International Law Review 18: 285-331.

Lundborg, T. (2012) Politics of the Event: Time, movement, becoming (London: Routledge)

McConnell, F. (2016a) Rehearsing the State: The Political Practices of the Tibetan

Government-in-Exile. Chichester: Wiley and Blackwell.

McConnell, F. (2016b) 'Liminal geopolitics: The subjectivity and spatiality of diplomacy at the margins,' Transactions of the Institute of British Geographers 42(1): 139-152.

McConnell, F. and Dittmer, J. (2018) 'Liminality and the diplomacy of the British Overseas Territories: an assemblage approach,' Environment and Planning D 36(1): 139-158.

McConnell, F., T. Moreau, and J. Dittmer (2012) 'Mimicking state diplomacy: The legitimizing strategies of unofficial diplomacies,' Geoforum 43(4): 804-814. 
The force of events: the 'Brexit interval' and popular aspirations for Gibraltarian diplomacy

McLafferty, S. (2016) 'Conducting questionnaire surveys' in Clifford, N., M. Cope, T.

Gillespie, and S. French (Eds.) Key Methods in Geography, Third Edition (London: SAGE), pp.129-142.

Mut Bosque, M. (2017) 'Brexit and the Commonwealth: New challenges for Gibraltar,' The Round Table: The Commonwealth Journal of International Affairs 106(4): 483-485.

Painter, J. (2006) ‘Prosaic geographies of stateness,' Political Geography 25(7): 752-774.

Pouliot, V. (2010). International Security in Practice: The politics of NATO-Russia diplomacy (Cambridge: Cambridge University Press).

Protevi, J (2009) Political Affect: Connecting the social and the somatic (Minneapolis: University of Minnesota Press).

Rankin, N. (2017) Defending the Rock: How Gibraltar defeated Hitler (New York: Faber \& Faber).

Reuters (2019) 'Spain claims success in Gibraltar row with Britain.' Online at:

https://www.reuters.com/article/us-britain-eu-visas/spain-claims-success-in-gibraltar-rowwith-britain-idUSKCN1RG199 (last accessed 15 July 2019).

Rezvani, D. (2016) 'Partial Independence Beats Full Independence,' Territory, Politics, Governance 4(3): 269-296.

Rezvani, D. (2019) 'Transforming fast and loose arguments into sound scholarly debate: a response to the critique of "partial independence beats full independence", Territory, Politics, Governance 7(3): 421-433.

Riegl, M., Doboš, B., \& Bečka, J. (2019) 'Independent territories revisited? The concept of partially independent territories (PITs) and the role of such territories in the international system.' Territory, Politics, Governance 7(3): 406-420. 
The force of events: the 'Brexit interval' and popular aspirations for Gibraltarian diplomacy

Sending, O. J., Pouliot, V., \& Neumann, I. B. (Eds.) (2015). Diplomacy and the making of world politics (Cambridge: Cambridge University Press).

Shaw, I. (2012) 'Towards an evental geography,' Progress in Human Geography 36: 613-627. UK Government (2019) ‘Operation Yellowhammer: HMG Reasonable Worst Case Planning Assumptions as of 2 August 2019'. Available online at https://assets.publishing.service.gov.uk/government/uploads/system/uploads/attach ment_data/file/831199/20190802_Latest_Yellowhammer_Planning_assumptions_CD L.pdf (last accessed 12 September 2019).

Visoka, G. (2019) 'Metis Diplomacy: The everyday politics of becoming a sovereign state,' Cooperation and Conflict 54(2): 167-190.

Walker, R.B.J., R. Shilliam, H. Weber, and G. Du Plessis (2018) ‘Collective Discussion: Diagnosing the present,' International Political Sociology 12(1): 88-107.

Widder, N. (2008) 'Foucault and the Event' International Political Sociology 2(3): 276-277). Wolff, S. (2007) 'Paradiplomacy: Scope, opportunities and challenges,' The Bologna Center Journal of International Affairs 10: 141-150. 